\title{
Persoonlijke contacten in vooroorlogse receptie van Nederlandstalige literatuur in Tsjechische vertaling*
}

\begin{abstract}
The paper concerns the influence of personal contacts on what has been translated from Dutch and Flemish literature into Czech before 1989. After a short introduction about Czech translation culture, the paper gives a survey of a couple of interesting cases. The first is the series 1000 nejkrásnějšich novell 1000 svétových spisovatelu (The 1000 most beautiful novels of 1000 world authors) from the beginning of the $20^{\text {th }}$ century. The second is the translator Jaroslav Kamper from the same period. The third is the Czech symbolist writer and translator Arnošt Procházka. The last case is the professional translator Lída Faltová, who made the first translations of Willem Elsschot's work. In all cases, a look is given how their personal contacts partly influenced their translation production.
\end{abstract}

Keywords: Dutch literature, Flemish literature, Czech translation, personal contacts, Jaroslav Kamper, Lída Faltová, Olga Krijtová

\section{Ter inleiding}

In deze bijdrage zal de receptie van Nederlandstalige literatuur in Tsjechische vertaling centraal staan. Als gevolg van tamelijk intensief onderzoek naar Tsjechische vertalingen van Nederlandstalige literatuur, vanaf ongeveer 1974 gedaan door Olga Krijtová (1931-2013), na 1994 vooral door de auteur van dit stuk, zijn er op dit moment ongeveer 311 titels van in het Tsjechisch vertaalde werken Nederlandstalige literatuur bekend voor de periode 1845-1948, de periode waar deze

* Deze bijdrage kwam tot stand als gevolg van het project FPVC 2016/02 "Recepce nizozemské a vlámské literatury v českém překladu, 1848-1948” van de Faculteit Letteren van de Univerzita Palackého te Olomouc. 
bijdrage aan gewijd is. Dat is bijna driemaal zoveel als in de andere Slavische talen bij elkaar - 111 titels. $^{1}$

Nemen we de periode tot aan de 'Wende' in 1989 in acht, toen er in Polen en Hongarije al vakgroepen Nederlands waren ontstaan die onder andere literaire vertalers opleidden, is het verschil minder pregnant: tegenover 'slechts' 487 vertalingen in het Tsjechisch tussen 1845 en 1989 staan 498 titels in de andere Slavische talen bij elkaar. Dat zijn in volgorde van aantallen vertaalde titels: Pools, Servokroatisch, Russisch, Sloveens, Slowaaks en Bulgaars.

Dit soort getallen moeten we met enige reserve nemen. Tsjechië beschikt over een geavanceerder systeem van registratie van onder andere tijdschriftartikelen dan de meeste andere landen in de regio. Wat Delpher is voor de Nederlandse kranten, is Kramerius voor Tsjechische kranten en tijdschriften. ${ }^{2}$ Er worden doorlopend nieuwe titels ingescand, wat de onderzoeker dwingt tot een regelmatige update van de gegevens. Als ik mijn eigen huidige gegevens vergelijk met die van pakweg tien jaar geleden, dan waren mij destijds voor de periode 1879-1948 slechts 197 vertalingen bekend. Met andere woorden ik weet nu over de helft meer vertalingen (114) en daarbij ook over zo'n 12 vertalingen die al vóór 1879 zijn verschenen en volstrekt onbekend waren. Dergelijke verrassingen zijn beslist niet uitgesloten voor de andere Slavische talen, maar vooralsnog mogen we er wel vanuitgaan dat er in het Tsjechisch ruwweg driemaal zoveel vertalingen uit het Nederlands aanwezig zijn als in de andere Slavische talen bij elkaar.

\section{Een verklaring}

Een logische verklaring is dat de Tsjechische boekenmarkt geografisch en ideologisch veel dichter bij de Duitse lag. Tsjechië bestaat ruwweg uit twee grote

${ }^{1}$ De aangegeven aantallen berusten op verschillende bronnen: a) de database van het Nederlands Letterenfonds (https://letterenfonds.secure.force.com/vertalingendatabase/); b) gedrukte gegevens in Engelbrecht 1995, Gera 2006, Havlíková 2004, Koch \& Morciniec 1985, 1986, Koch 1993, Krijtová, Pellar \& Schürová 1994, 2003, Linzbotková \& Molnár 1989, Maňáková \& Engelbrecht 2006, Scheltjens 2003, Szábo \& Beke 2001; c) de gegevens van de electronische catalogi van de BibliotekaNarodowa in Warschau (http://www.bn.org.pl/katalogi-i-bibliografie), de Национална библиотека „Свети Свети Кирил и Методий“ te Sofia (http://www.bg.cobiss.net/), de Narodna in Univerzitetna Knjižnica te Ljubljana (http://www.nuk.uni-lj.si/viri/katalogi), de Národní knihovna v Praze te Praag (www.nkp.cz), de Országos Széchényi Könyvtar te Boedapest (http://nektar2.oszk.hu/librivision_hun. html), het Ossolineum in Wrocław (https://ossolineum.pl/), de Slovenská národná knižnica in Martin (http://www.snk.sk/sk/katalogy.html).

${ }^{2}$ URL: Kramerius.nkp.cz. Er kan ook gezocht worden in de deelverzamelingen, voor kranten uit de regio Noord-Moravië bijvoorbeeld http://noviny.vkol.cz/kramerius. Voor 1920 verschenen artikelen zijn meestal vrij opvraagbaar, voor de periode 1920-1947 kunnen artikelen in de wetenschappelijke bibliotheken vrij worden ingezien en afgedrukt. Recenter materiaal moet worden aangevraagd. 
delen, die tot 1948 min of meer aparte Länder vormden: Bohemen en Moravië. ${ }^{3}$ Bohemen - met het grote culturele centrum Praag, maar met daarnaast nog belangrijke kleinere centra als Plzeň en tot 1945 voor de Duitstalige Tsjechische cultuur ook Reichenberg (Liberec) en České Budějovice (Budweis) - was sterk op Rijksduitsland gericht. Uitgevers in dit gebied stelden zich meestal op de Leipziger Buchmesse op de hoogte van belangrijke nieuwe titels. Moravië, getalsmatig én ook cultureel het kleinere landsdeel, waar de beide centra Brno en Olomouc bovendien tot 1945 goeddeels door de Duitstalige minderheid werden overheerst, was op Oostenrijk, met name op Wenen gericht. In Oostenrijk kwamen er veel minder vertalingen uit het Nederlands uit dan in Duitsland. Daar staat tegenover dat de enige serieuze Duitstalige uitgeverij voor de bellettrie zich in Brno (Brünn) bevond. Dat was Rudolf Rohrer-Verlag, een in 1786 gestichte uitgeverij die tot 1945 hier bestond. ${ }^{4}$ Bij deze uitgeverij werden in de jaren ' 40 de Duitse vertalingen van Vestdijks werk uitgegeven, zover bekend de enige vertalingen van Nederlandstalige literatuur die in Duitstalig Tsjechisch gebied zijn uitgegeven.

De verhouding tussen het aantal vertalingen in het Duits - voor diezelfde periode 1845-1989 goed voor ongeveer 3000 titels $^{5}$ - en die in het Tsjechisch is periode ruwweg 6:1. Dat is niet zo'n slechte score, als we bedenken dat er in 1921 slechts 6,8 miljoen Tsjechischtaligen tegenover ruim 75 miljoen Duitstaligen (van wie 3,1 miljoen binnen Tsjechië zelf) waren - een verhouding van 11:1. Bovendien blijken bij nader onderzoek rechtstreekse contacten met de Lage Landen een rol te spelen. Hierop verderop in deze bijdrage meer.

\section{De vertaalcultuur}

Het Tsjechisch stond binnen Tsjechië zelf sinds de in 1618-1621 verloren opstand tegen de Habsburgers op het tweede plan. De taal werd zoetjesaan steeds meer uitsluitend als een 'huistaal' gezien. De openbaarheid behoorde aan het Duits toe. Een situatie die Vlamingen niet onbekend voor zal komen. Dit veranderde in 1774 na de invoering van de leerplicht tussen zes- en twaalfjarige leeftijd in alle Habsburgse gebieden door keizerin Maria Theresia. Opeens waren er voor alle officiele talen in het rijksgebied grammatica's en leerboeken nodig. Dit was een van

${ }^{3}$ Dit landsdeel omvatte sinds 1928 ook Silezië (een restgebiedje van het grote koninkrijksdeel Silezië dat in 1742 grotendeels bij Pruisen werd gevoegd en tegenwoordig merendeels Polen is), tot die tijd een apart gebiedsdeel met een eigen hoofdstad en landdag.

${ }^{4}$ De uitgeverij had vanaf begin $20^{\mathrm{e}}$ eeuw ook filialen in München en Wenen en was een van de belangrijkste Oostenrijks-Hongaarse uitgeverijen. De uitgeverij voerde in 1831 de eerste rotatiepers en meerkleurendruk in Tsjechië in en was in 1905 de eerste voor de hele Dubbelmonarchie om op monotype-zetmachines over te gaan. Na de Tweede Wereldoorlog ging de uitgeverij verder in Innsbruck (Vierhaus 2007: 507).

${ }^{5}$ De aantallen voor het Duits op basis van Van Uffelen 1993. 
de belangrijkste impulsen voor de Tsjechische 'Nationale Wedergeboorte' die tot ruwweg 1860 duurde.

Met name in de tweede fase van deze wedergeboorte (1800-1830) propageerde de schrijver en lexicograaf Josef Jungmann (1773-1847) vertalingen als een mogelijkheid om het Tsjechisch te verrijken. Hoewel hij daarbij vooral dacht aan adaptatie van woorden uit het Pools en het Russisch in het Tsjechisch, droegen bijvoorbeeld ook Jungmanns vertalingen uit het Frans en Engels, zoals zijn vertaling Ztracený rág (1811) van Miltons Paradise Lost bij tot de verrijking van de taal. De Vlamingen werden in deze periode als een lichtend voorbeeld beschouwd van een volk dat erin was geslaagd om zich het (Hollandse) vreemde juk af te schudden en dat vervolgens tegen de Franse taalkundige overheersing vocht. Als gevolg daarvan was werk van Hendrik Conscience de eerste Nederlandstalige literatuur die in het Tsjechisch werd vertaald. De Tsjechische activist en parlementsafgevaardigde František Kampelík (1805-1872) voegde aan zijn tractaat Obrana českého jazyka (Verdediging van de Tsjechische taal, 1847) zelfs een bijlage toe, waarin Consciences oproep tot eenheid van de Vlamingen in Vlaemsch België van 12 maart 1844 in Tsjechische vertaling was afgedrukt. Overigens werden die eerste vertalingen uit 1846 - Wat een moeder lyden kan en Siska van Rosemael - op basis van de Duitse vertaling uit 1845 van Melchior von Diepenbrock (17981853) gemaakt (Engelbrecht 2016: 240-242).

Waar Jungmann in zijn tractaat Slowesnost (Literatuur, 1846) nog vertalingen propageerde die de brontekst zoveel mogelijk aan het Tsjechisch aanpasten, werd deze praktijk al korte tijd later onderwerp van heftige discussies. Jakub Malý (1811-1885), zelf succesvol vertaler (en één van de vertalers van de eerste vertalingen van Conscience uit 1846) schreef in 1854 een fundamenteel artikel O překládání klassikù (Over het vertalen van de klassieken), waarin hij betoogde dat 'klassieke auteurs' als Shakespeare rechtstreeks uit de brontaal dienden te worden vertaald en met zo min mogelijk aanpassingen aan de Tsjechische realiteit. Bij populaire lectuur - Malý geeft als voorbeeld de destijds zeer populaire Franse schrijver Paul de Kock (1793-1871) die qua enorme productie en genre sterk met Conscience vergelijkbaar was - achtte Malý adaptatie (de Tsjechen spraken van localisatie of vertsjechising) juist wenselijk. Hieruit blijkt dat hij de destijds in het Tsjechisch vertaalde werken van Conscience niet als 'klassieke literatuur' beschouwde (Engelbrecht 2013: 220-222).

Als gevolg van deze discussie bestaat sindsdien in Tsjechië de praktijk dat high brow literatuur uitsluitend rechtstreeks uit de brontaal naar de doeltaal (het Tsjechisch) wordt vertaald. Het gebruik van een tussentaal beschouwt men als onprofessioneel gedrag. Voor een relatief exotische taal als het Nederlands werkt dit beperkend. Het verklaart waarschijnlijk ook mede waarom De Leeuw van Vlaenderen van Conscience pas in de $20^{\mathrm{e}}$ eeuw werd vertaald - dat werk werd in Tsjechië, anders dan zijn veelvuldig vertaalde sociale novellen,van meet af aan als 'high brow' literatuur beschouwd. Overigens zullen ook het kostenaspect - vrijwel al Consciences in 
de $19^{\mathrm{e}}$ eeuw vertaalde werken zijn korte novelles die in uitermate goedkope edities of als feuilleton uitkwamen - en het feit dat de in literatuur geïnteresseerde hoger opgeleide Tsjech meestal goed Duits en Frans las (en dit soort werken dus in die talen kon lezen), een rol hebben gespeeld (vgl. Engelbrecht 2016b: 175).

\section{Het geval 1000 nejkrásnějšich novell}

Wanneer dit esthetisch-translatologische 'gebod' toch werd ontdoken, probeerde men vaak krampachtig te verdoezelen dat er voor de vertaling een tussentaal was gebruikt. Het mooiste voorbeeld van zulk gedrag is aanwezig in de prestigeuze serie 1000 nejkrásnějšich novell 1000 světových spisovatelů (De 1000 mooiste novelles van 1000 wereldauteurs). Deze serie werd gepubliceerd tussen juni 1911 en augustus 1916 door de destijds toonaangevende Tsjechische uitgeverij J.R. Vilímek in Praag. Vilímek gaf wel vaker literaire series uit en deze was net als de andere reeksen gebaseerd op een abonnementsysteem. De afnemers zouden tien jaar lang tweemaal per maand een aflevering met vier tot zes novelles ontvangen, waarbij elke aflevering precies 100 pagina's had. De serie stopte na 102 afleveringen met in totaal 499 novelles vrij plotseling in augustus $1916 .{ }^{6}$ De Tsjechische vakliteratuur geeft papierschaarste tijdens de Eerste Wereldoorlog als oorzaak aan (Zach 2008: 1343).

Bij nader inzien moet er iets anders aan de hand zijn geweest. Om te beginnen werden andere series zoals Vilímkova knihovna (Vilímeks bibliotheek) gewoon voortgezet, wat het argument 'papierschaarste' onlogisch maakt. Bij toeval stuitte ik op het artikel van Luc Daems (2000) over de Franse serie Les Milles Nouvelles Nouvelle die tussen februari 1910 en februari 1912 uitkwam in Parijs bij uitgeverij Jean Gillequin met imprint La Renaissance du Livre. Niet alleen lijken opzet en layout van de Tsjechische en Franse serie sterk op elkaar - zowel het formaat, de opzet in afleveringen, de omslag, als ook de inleidingen - maarbovendien waren zes van de acht in het Tsjechisch vertaalde Nederlandstalige novelles eerder in de Franse serie uitgekomen. De titels van de Tsjechische vertalingen sluiten bij de Franse aan (zie onderstaande tabel).

Tabel 1. Overzicht van de in Les Mille Nouvelles Nouvelles en 1000 nejkrásnějších novell in vertaling gepubliceerde Nederlandstalige verhalen

\begin{tabular}{|l|l|l|}
\hline \multicolumn{1}{|c|}{ Origineel werk } & \multicolumn{1}{|c|}{ Franse uitgave } & \multicolumn{1}{c|}{ Tsjechische uitgave } \\
\hline $\begin{array}{l}\text { Pieter van der Meer, Banden, } \\
\text { uit: Het Geheime (1906) }\end{array}$ & Le lien (LMNN 3, april 1910) & $\begin{array}{l}\text { Pouta (1000 NN 45, maart } \\
1913)\end{array}$ \\
\hline
\end{tabular}

${ }^{6}$ Nog op 4 augustus 1916 had de uitgeverij trots in haar reclames aangekondigd dat de eerste helft van de serie al was uitgegeven en dat men zich nu opmaakte voor de tweede helft. Vervolgens alleen diepe stilte. 


\begin{tabular}{|l|l|l|}
\hline $\begin{array}{l}\text { Stijn Streuvels, De doodend- } \\
\text { ans (1901) }\end{array}$ & $\begin{array}{l}\text { La Ronde de la mort (LMNN } \\
\text { 6, juli 1910) }\end{array}$ & $\begin{array}{l}\text { Koloběh smrti (1000 NN 20, } \\
\text { april 1912) }\end{array}$ \\
\hline $\begin{array}{l}\text { Job Steynen, De loods, uit } \\
\text { Verbijsterden (1906) }\end{array}$ & $\begin{array}{l}\text { Le pilote (LMNN 7, augustus } \\
\text { 1910) }\end{array}$ & $\begin{array}{l}\text { Lodivoda (1000 NN 62, janua- } \\
\text { ri 1914) }\end{array}$ \\
\hline $\begin{array}{l}\text { Louis Couperus, Een zieltje, } \\
\text { uit Eenellluzie (1892) }\end{array}$ & $\begin{array}{l}\text { Une petite ame (LMNN 9, } \\
\text { oktober 1910) }\end{array}$ & $\begin{array}{l}\text { Dětská dušicka (1000 NN 25, } \\
\text { juni 1912) }\end{array}$ \\
\hline $\begin{array}{l}\text { CyrielBuysse, Le cheval, uit } \\
\text { Petits Contes (1895) }\end{array}$ & $\begin{array}{l}\text { Le cheval (LMNN 11, novem- } \\
\text { ber 1910) }\end{array}$ & $\begin{array}{l}\text { Kůn̆ (1000 NN 16, februari } \\
1912)\end{array}$ \\
\hline $\begin{array}{l}\text { Nederlandse versie Het Paard } \\
\text { in Uit Vlaanderen (1899) }\end{array}$ & $\begin{array}{l}\text { La chanson de Peer Lobbe } \\
\text { (LMNN 19, augustus 1911) }\end{array}$ & $\begin{array}{l}\text { Píseň o Peer Lobbeovi (1000 } \\
\text { NN 57, oktober 1913) }\end{array}$ \\
\hline $\begin{array}{l}\text { Herman Teirlinck, Het lied } \\
\text { van Peer Lobbe (1910) }\end{array}$ & \multicolumn{2}{|l}{ (19) } \\
\hline
\end{tabular}

Vergelijking van de Tsjechische en de Franse vertalingen toont dat de Tsjechische versie in alle gevallen op de Franse tekst teruggaat. Het beste is dat te zien bij Couperus' verhaal Een zieltje (1912), waarvan nog twee Tsjechische vertalingen bestaan (Couperus 1896, 1902), waarbij één daarvan vrij zeker uit het Nederlands is vertaald. ${ }^{7}$ Als enige van de drie vertalingen gebruikt de versie in 1000 nejkrásnějšich novell voor de protagonist Kareltje de naam Charlot, wat overeenkomt met de Franse vertaling. Deze naam is in het Tsjechisch hoogst ongebruikelijk. De beide andere vertalingen geven zijn naam weer met Karlik of Karliček, de correcte Tsjechische varianten van het Nederlandse Kareltje.

Net als in de Franse serie werd de vertaling van een novelle in de deeltjes van 1000 nejkrásnějších novell steeds voorafgegaan door een korte biografie - in het Tsjechisch met medailon aangeduid. In alle zes de gevallen heeft de schrijver van het 'medaillon' overduidelijk de Franse tekst bij de hand gehad en heeft steeds de moeite genomen om die zo te ordenen dat er als het ware een andere tekst ontstond. Opmerkelijk is ook dat de Tsjechische vertaler meestal niet is genoemd, wat tegen de Tsjechische translatologische conventies van die tijd inging.

De redacteur van de Tsjechische serie was František Sekanina (1875-1958) die zelf een bekende dichter en literair criticus was. Bovendien was hij actief als literair vertaler uit het Frans, zo had hij in 1905 de eerste Tsjechische bloemlezing van de gedichten van Paul Verlaine in boekvorm verzorgd. Door de vertalingen van Les Mille Nouvelles Nouvelles te mixen met originele Tsjechische en Slowaakse teksten, en met vertalingen die al in tijdschriften waren uitgekomen,

${ }^{7}$ V. Kuneš vermeldt uitdrukkelijk dat zijn vertaling (Couperus 1896) geautoriseerd was. In de correspondentie van Couperus met uitgever Veen is hierover niets terug te vinden. 
kon Sekanina relatief snel een mooie serie opbouwen. Toen de Franse serie in februari 1912 stopte, moet dit een lelijke streep door zijn rekening zijn geweest. Het is hem kennelijk niet gelukt om het zo gevallen gat te dichten. ${ }^{8}$

Maar dit soort gevallen waren uitzonderingen. Zeker vanaf de eeuwwisseling werden Nederlandstalige werken in toenemende mate inderdaad rechtstreeks vertaald - al zal de vertaler zo nu en dan wel een Duitse of Franse vertaling bij de hand hebben gehad, zoals uit het hierna volgende voorbeeld zal blijken. Een opmerkelijk gegeven is dat er soms boeken in het Tsjechisch werden vertaald die níet of pas veel later in een van beide genoemde belangrijke tussentalen beschikbaar waren. Daar kan van tussentaal uiteraard geen sprake zijn geweest. Hier wil ik kort op een paar interessante vertalingen ingaan.

\section{De 'Nederlandse Tsjech' Jaroslav Kamper}

Wanneer de Tsjechische schrijver en literair criticus Jaroslav Kamper (1871-1911) in 1896 zijn vertaling Osud van de roman Noodlot (1890) van Couperus uitgeeft bij de reeds genoemde uitgeverij Vilímek, verdedigt hij in zijn inleiding op voorhand taalkundige ingrepen in zijn vertaling (Couperus 1896b: xi-xii): ${ }^{9}$

Aan het eind zij mij een paar woorden vergund over de vertaling van "Noodlot". Dat de vertaling van een boek van een zo persoonlijke auteur, die een emotionele en karakteristieke stijl vol details bezigt, op zichzelf al geen makkelijk werk is, zal eenieder toegeven die ook maar een vluchtige blik in het boek werpt. Dat werk werd nog bemoeilijkt door het speciale, zo van de geest van onze taal afwijkende karakter van het Hollands. [...] Een simpele vergelijking van mijn vertaling met de Duitse vertaling (waar, al was de vertaling veel makkelijker, hele stukken zijn weggelaten en veel ook onjuist is vertaald) is, denk ik, voldoende bewijs dat ik me het werk niet makkelijk heb gemaakt. Ik doe slechts mijn aangename plicht, als ik de heer Jaroslav Hladík in Amsterdam hartelijk dank zeg voor menige nuttige wenk die hij mij vriendelijk bij het werk heeft verstrekt.

De genoemde "Duitse vertaling" moet die van Paul Raché uit 1892 zijn geweest die Kamper dus ter beschikking had. Kamper was er vast van overtuigd dat zijn familie van Nederlandse origine was en uit Kampen stamde, en behoorde tot de eerste Tsjechische literaire critici die systematisch Nederlandse literatuur behandelden. ${ }^{10}$ Hij introduceerde bijvoorbeeld de Tachtigers in Tsjechië. Zijn ver-

${ }^{8}$ De Franse herkomst van een deel van de vertalingen verried zich onwillekeurig ook bij de Tsjechische opmerking bij de teksten van Georges Eekhoud, Le coq rouge (in het Tsjechisch Červený kohout, bandje 22, mei 1912) en Hubert Krains, L'îlet rouge (in het Tsjechisch Duše domu, bandje 43, januari 1913) dat deze uit het Vlaams zouden zijn vertaald. Omdat beide teksten toch echt alleen in een Frans origineel bestaan, is duidelijk dat de vertaler de - in het Frans correcte - opmerking dat het om Vlaamse schrijvers gaat, want Franstalige Vlamingen (Flamands), verkeerd heeft begrepen.

${ }^{9}$ Alle vertalingen uit het Tsjechisch in dit artikel zijn door de auteur gemaakt.

10 Zie voor Kamper en de receptie van de Tachtigers in het Tsjechisch in extenso Engelbrecht \& Vaidová 2013. 
wijzing naar de heer Jaroslav Hladík in Amsterdam intrigeert én verklaart. Bij zijn recensies in de Tsjechische literaire pers lijkt Kamper kennis te hebben van De Nieuwe Gids. Met de toenmalige communicatiemiddelen een raadsel. Maar dit wordt al minder raadselachtig, als we weten dat Kamper getrouwd was met Emilie Hladíková (1874-na 1913), een zus van de genoemde Jaroslav Hladík (1872-1896) én ook van de literair criticus Václav Hladík (1868-1913). Jaroslav Hladík was na zijn studie bij de handelsacademie bij verschillende buitenlandse banken werkzaam geweest om uiteindelijk in 1896 bij de NV Fondsenbank in Den Haag terecht te komen. Bovendien was hij zelf in zijn vrije tijd actief als vertaler van o.a. L'Argent (1891) van Zola en Charles Demailly (1860) van de gebroeders Goncourt. Zijn broer Václavwas mogelijk identiek met de eerder genoemde Tsjechische vertaler V. Kuneš van wie uitsluitend in de jaren 1896-1898 verschillende vertalingen uitkwamen in het tijdschrift Lumir, waarvan Kamper redacteur was, of in boekvorm bij Otto in Praag. Opmerkelijk is dat V. Kuneš ná de dood van Jaroslav Hladík niets meer vertaalde. Het contact was verloren gegaan.

\section{Arnošt Procházka, de French connection}

Een soortgelijk contactpunt moet de Tsjechische decadente schrijver Arnošt Procházka (1869-1925) hebben gehad. Procházka interesseerde zich zeer voor de Franse symbolisten met wie hij zich poëticaal verwant voelde. In zijn in 1894 opgerichte tijdschrift Moderní revue gaf Procházka verschillende vertalingen van Franse symbolisten uit. Het bekendste is zijn vertaling van $A$ rebours (1884) van Joris-Karl Huysmans. In het tijdschrift treffen we verschillende bekende Nederlandstalige schrijvers aan (Engelbrecht 2014). Direct in de eerste jaargang van 1894 wordt Droom (1892) van Frans Erens afgedrukt, later Egidius en de vreemdeling (1899) van Willem van Nouhuys, Het krabbetje en de gerechtigheid (1887) van Frederik van Eeden, Saffo's zang (1894) van Betsy Juta en Sluimer (1891) van Jacques Perk. Procházka's vertalingen van Het krabbetje en de gerechtigheid en Egidius en de vreemdeling werden in respectievelijk bandje 16 (februari 1912) en bandje 32 (oktober 1912) van de hierboven besproken serie 1000 nejkrásnějších novell opnieuw afgedrukt.

Procházka vertaalde in 1905 De kleine Johannes (1885) van Van Eeden. Over deze vertaling had hij meermalen contact met de schrijver (Vaidová 2014). Maar hoewel Procházka meermalen stelt dat hij rechtstreeks uit het Nederlands vertaalde en hij minstens passief ook Nederlands kende, is het de vraag of we hem helemaal op zijn woord mogen geloven. Opvallend is namelijk dat zijn correspondentie met Van Eeden in het Frans verliep, en dat er voor al de door Procházka vertaalde werken eerdere Franse vertalingen blijken te bestaan. Deze werden vooral door Georges Khnopff (1860-1927) gemaakt (Dessy 2014). Droom verscheen zelfs voor het eerst in 1892 in een tweetalige uitgave in het tijdschrift Mercure 
de France. $\mathrm{Nu}$ stond de kring rond Moderni revue in verbinding met de Brusselse groep van Les XXs, waartoe de bekende Frans-Belgische symbolist Fernand Khnopff(1858-1921, de oudere broer van Georges) behoorde, van wiens werk verschillende afbeeldingen in Moderní revue zijn overgenomen (Engelbrecht 2014).

In dit licht gezien zou het niet verbazen, als Procházka via zijn FranstaligBelgische connecties kennis had gemaakt met de door hem gekozen Nederlandse literatuur en hij bij zijn vertaling van De kleine Johannes van Van Eeden uit 1905 de Franse vertaling van Georges Khnopff bij de hand had gehad die in 1903 in $L a$ Plume was verschenen (Dessy 2014). Alleen kon hij dit moeilijk openlijk vertellen, omdat 'hogere literatuur' immers rechtstreeks moest worden vertaald uit de brontaal. Opvallend is wel dat Procházka nimmer Nederlandstalige werken vertaalde die niet al eerder in het Frans waren uitgekomen.

\section{Lída Faltová}

In het Interbellum is de enorme activiteit van Tsjechische vertalers in vergelijking met de situatie in andere Slavische talen opmerkelijk - 210 vertalingen in het Tsjechisch tegenover slechts 68 in de andere talen bij elkaar. In Tsjechië komt dan het fenomeen op van personen die van literair vertalen hun beroep maken en zich in een paar talen specialiseren. Voor het Nederlands waren dat met name de diplomaat Rudolf J. Vonka (1877-1964) en zijn echtgenote Linda Vonková (1884-1959), en de literair vertaalster Lída Faltová (1899-1944). Faltová was verreweg de belangrijkste: in haar eentje maakte zij 53 van de genoemde 210 Tsjechische vertalingen van Nederlandstalige literatuur uit het interbellum, dus ruim een kwart van wat destijds verschenen is.

Allereerst valt op dat Faltová een mix vertaalde van wat we nu als middle brow en high brow auteurs aanduiden. Omdat zij van haar vertalingen moest leven en middle brow auteurs meestal beter verkopen dan hun 'literairdere' collega's, is dat logisch. We treffen bij de door haar vertaalde werken uiteraard werk van auteurs aan die in heel Centraal-Europa populair waren - Antoon Coolen en Madelon Székely-Lulofs, in de jaren vlak voor en tijdens Wereldoorlog II ook de Vlaamse auteurs Stijn Streuvels en Felix Timmermans. In sommige gevallen blijkt uit de uitgeversarchieven dat de onderhandelingen over auteursrechten tussen de Tsjechische en de Nederlandse uitgeverijen via Tsjechische literaire agenturen verliepen. Deze brieven zijn helaas slechts sporadisch bewaard gebleven en archieven van deze agenturen zijn mij tot mijn spijt niet bekend. ${ }^{11}$

In dergelijke gevallen kreeg Faltová meestal het verzoek om één van de twee leesrapporten op te stellen die uitgevers in het algemeen vroegen, voordat het be-

11 Twee agenturen die voor Nederlands bemiddelden waren Centrum van Míla KholováToušlová (1894-1954) en Gustav Bernau (1906-1986). Zo bemiddelde Bernau bijv. bij De Vlaschaard van Streuvels. 
sluit werd genomen om een boek te laten vertalen en vaak werd de opdracht aan haar toegekend.

Maar in enkele gevallen stelde zij zelf de boeken ter vertaling voor. Dat zijn vaak de interessantste gevallen. Opvallend is dat er in het Tsjechisch een vrij grote reeks titels van Johan Fabricius aanwezig is. Het gaat meestal om boeken die wel in het Duits werden vertaald, maar in andere Slavische talen en het Hongaars ontbreken. En dan zijn er enkele buitengewoon opvallende titels. Zo was Faltová de énige vertaler die al in het Interbellum Kaas van Willem Elsschot vertaalde, het boek kwam in 1936 slechts drie jaar na de publicatie van het origineel in Forum uitin een bundel samen met Tsjip (1934) bij Julius Albert in Praag (Engelbrecht 2017: 257). Ze vertaalde in 1937 Jef Lasts In de loopgraven voor Madrid (1936), een vertaling die haar overigens op nogal wat kritiek kwam te staan van abonnenten van haar hoofduitgever Družstevní práce (De Collectieve Arbeid), maar die haar man, het sociaal-democratische parlementslid Josef Falta (1895-1974) in het tijdschrift Panorama met verve verdedigde (Falta 1937). Onder de Vlamingen vallen Gerard Walschap en Lode Zielens op. Walschap was relatief vaak in het Duits vertaald, zodat deze vertaling wel op verzoek van de uitgever zal zijn gemaakt. ${ }^{12}$ Maar Faltová vertaalde ook twee werken van Lode Zielens, waarbij het tweede, Moeder waarom leven wij? (1933), wegens de oorlog niet meer uitkwam. Het complete manuscript ligt in het archief van Družstevní práce. ${ }^{13}$

Opmerkelijk is ook wat Faltová niet vertaalde - de in Centraal-Europa alom tegenwoordige Jo van Ammers-Küller is een opvallende afwezige in het oeuvre. Een zéér opvallende afwezige, want haar thematiek moet de Tsjechische vrouwen hebben aangesproken, én de romans over de familie Coornvelt waren in Duitsland, Polen en Hongarije een regelrecht kassucces. De schrijfster had bovendien in 1933 zelf contact opgenomen met Družstevnípráce en haar romans ter vertaling aangeboden, met een verwijzing naar het Duitse succes. De uitgever had dit echter beleefd afgewimpeld. ${ }^{14}$ Deze uitzonderingen wijzen op rechtstreekse contacten van Faltová met Nederlandstalige insiders. De meest in aanmerking komende contactpersoon is Johan Fabricius die zijn vertaalster in 1934 kwam opzoeken (Faltová 1934). Fabricius was lid van PEN-Nederland en was in 1933 op eigen houtje op het geruchtmakende PEN-congres in Dubrovnik aanwezig geweest.

12 Map PNP 70/57 nr. 107 Walschap van het archief van Družstevní práce geeft hier geen uitsluitsel over. Sommige boeken, zoals Adelaïde, waren wel aan DP aangeboden maar kwamen na de Tweede Wereldoorlog bij andere, kleinere uitgevers uit, meestal vanwege de papierdistributie van staatswege.

${ }^{13}$ Uit het archief en de redactiestukken van de uitgeverij blijkt dat de vertaling was gepland voor november 1936. Omdat Faltová nog niet klaar was met de vertaling werd de uitgave verschoven naar november 1937, uiteindelijk was de planning november 1938 (map PNP DP 70/57 redakční rada). Omdat de zgn. Tweede Republiek van autoritaire 'austrofascistische' signatuur op 1 oktober 1938 was opgericht, was de uitgave kennelijk 'niet opportuun' meer.

${ }^{14}$ Brief van 11 november 1933 aan DP met negatief antwoord van DP van 20 november 1933. PNP fond 70/57, map Ammers. 
Jammer genoeg is het privé-archief van Faltová verloren gegaan en zijn sommige uitgeversarchieven als gevolg van de nogal plotselinge inbeslagname eind jaren ' 40 slechts zeer fragmentarisch bewaard gebleven. ${ }^{15}$ Faltová zal zowel van Fabricius als van het Tsjechische PEN-lid Karel Č́apek (1890-1938), die overigens in 1934 ook door Fabricius met een bezoek werd vereerd, van het schandalige optreden van Van Ammers-Küller op het PEN-congres in Dubrovnik hebben gehoord, waar zij openlijk de kant van de Nazistische Duitse delegatie had gekozen. Huisuitgever Družstevní práce had overigens nogal wat "entartete Schrifsteller" in zijn bestand en was daar ook trots op ${ }^{16}$ - hiermee was Van Ammers-Küller als potentiële uit te geven schrijfster automatisch gedeclasseerd. De uitgeverij liet dus om ideologische redenen potentiële verkoopsuccessen schieten (Engelbrecht 2017: 261-262).

\section{Conclusie}

In de jaren dertig van de twintigste eeuw kwamen de eerste overzichten van vertalingen van Nederlandstalige literatuur uit. De regionale Vlaamse schrijver Prosper Arents (1889-1984) maakte in 1931 een overzicht voor Vlaamse literatuur en de apotheker Antonius J. van Huffel (1865-1947) maakte in 1939 een samenvattend overzicht van alle hem bekende vertalingen van in Nederland uitgegeven Nederlandstalige literatuur (van Huffel 1939, 1946). ${ }^{17}$ Dat een groot deel van de Nederlandstalige auteurs die voorkomen in deze boekjes ook in Tsjechische vertaling verschenen is geen toeval. De belangrijke Tsjechische uitgeverijen kwamen op de jaarlijkse boekenbeurs in Leipzig, waar zij hun licht opstaken over interessante in het Duits vertaalde boeken. Daarnaast maakte literaire agenturen

${ }^{15} \mathrm{Na}$ een korte overgangsperiode, waarin serieus de vernietiging van alle archivalia werd overwogen om zo het 'bourgeoisverleden' van Tsjechoslowakije volledig uit te wissen, werden de archieven van de opgeheven uitgeverijen merendeels naar het Nationaal Museum te Praag overgebracht. Dat had al sedert 1818 een afdeling die geschonken nalatenschappen van schrijvers beheerde. Omdat met de opheffing van alle private uitgeverijen en de confiscatie van veel particulier bezit de omvang van deze afdeling enorm groeide, werd in 1953 in het destijds opgeheven Strahovklooster het Památník národního písemnictví (Nationaal Literair Archief) opgericht. Vanaf 1972 worden alle fondsen systematisch gecatalogiseerd, hoewel enkele van de grootste (bijv. dat van uitgeverij Vilímek) nog steeds op catalogisatie wachten. In 2009 werd besloten om een oud militair fort in Litoměřice om te bouwen tot geklimatiseerde en bomvrije magazijnen. Deze operatie werd in oktober 2016 met een vertraging van ruim drie jaar afgesloten. Inmiddels worden alle archivalia systematisch naar dit nieuwe magazijn overgebracht.

${ }^{16}$ Op de omslag van aflevering 4 van jaargang 11 (1933) van Panorama was een paginagrote foto van de boekverbranding in Neurenberg afgedrukt met de opmerking "Op 10 mei 1933 werden

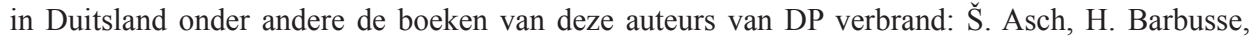
B. Brehm, A. Doeblin, L. Feuchtwanger, G. Fink, U. Sinclair, F. Unruh, J. Wassermann, A. Zweig. Kan er een betere aanbeveling voor deze boeken zijn dan dat Hitler ze liet verbranden?"

17 Van Huffel had sinds 1910 tot vrijwel aan zijn dood voor Uitgeverij Martinus Nijhoff de uitgave Nijhoff's Index op de Nederlandsche periodieken van algemeenen inhoud verzorgd. 
uitgeverijen op titels attent. Bovendien was het gebruikelijk dat literare vertalers zelf ook boeken voorstelden.

In het algemeen volgde de Tsjechische uitgeverswereld de trends die in het Frans (vooral tot begin jaren twintig) en in het Duits aanwezig waren. Opvallende afwijkingen van algemene Centraal-Europese trends zijn indicaties van persoonlijke contacten van Tsjechische vertalers met het Nederlandse taalgebied. Voorbeelden daarvan zijn de vroege vertaling van Elsschots werk, vertalingen van werk van Jef Last en Lode Zielens, en de afwezigheid van Tsjechische vertalingen van de bestsellers van Jo van Ammers-Küller.

\section{Bibliografie}

Arents, Prosper (1931): De Vlaamsche Schrijvers in vertaling. 1830-1931. Proeve van Bibliographie. Brussel: Standaard Boekhandel.

Couperus, Louis (1896a): "Dušička”. In: Lumír 29, 16: 186-189. Vertaling door V. Kuneš van Een zieltje.

Couperus, Louis (1896b): Osud. Praha: J.R. Vilímek. Vertaling door Jaroslav Kamper van Noodlot. Couperus, Louis (1902): “Ubohá dušička". In: Moravská orlice 40 (18-19 juli 1902): 163-164. Anonieme vertaling van Een zieltje.

Couperus, Louis (1912): "Dětská dušička". In: 1000 nejkrásnějšich novell 1000 světových spisovatelů 25. Praha: Vilímek, z.j. (juni 1912). Vertaling door J. Mužík van Een zieltje.

Daems, Luc (2000): “'Les Milles Nouvelles Nouvelles'. Vlaamse en Nederlandse novellen in vroege Franse vertaling van Pieter van de Meer de Walcheren, inzonderheid Streuvels' 'Doodendans' of 'La Ronde de la Mort'”. In: Verslagen en Mededelingen van de Koninklijke Academie voor Nederlandse Taal- en Letterkunde 110, 1: 107-158.

Dessy, Clément (2014): "Georges Khnopff ou la reconversion cosmopolite de l'homme des lettres". In: Textyles. Revue des lettres belges de langue française 45: 47-67.

Engelbrecht, Wilken (2005): "Zlaté ostruhy, kapitán Bontekoe, modré pondělky... K obrazu nizozemské literatury v Čechách”. In: Hrala, Milan \& Sotolová, Johanka (ed.): Český překlad II (1945-2004). Sbornik príspěvkĩ z kolokvia, které se konalo v Ústavu translatologie FF UK $v$ rámci výzkumného záméru Základy moderního světa v zrcadle literatury a filozofie (MSM 0021620824) v Praze 8. dubna 2005. Praha: Univerzita Karlova v Praze: 27-243.

Engelbrecht, Wilken (2013): “A Moravian Picture of Dutch Literature”. In: Zehnalová, Jitka e.a. (ed.): Tradition and Trends in Trans-Language Communication, Olomouc Modern Language Series 2. Olomouc: Palacký University, 215-228.

Engelbrecht, Wilken \& Vaidová, Zuzana (2013): “De Tachtigers door de ogen van de Tsjechische 'Negentigers"'. In: Besamusca, Emmeline e.a. (ed.): Out of the Box. Über den Wert des Grenzwertigen. Wien: Praesens Verlag, 193-210.

Engelbrecht, Wilken (2014): "Literatuur en kunstuit de Lage Landen in Moderní revue". In: Degand, Liesbeth e.a. (ed.): In het teken van identiteit. Taal en cultuur van de Nederlanden. Huldeboek aangeboden aan Prof. dr. Ludo Beheydt. Louvain-la-Neuve: UCL Presses Universitaires de Louvain, 85-92.

Engelbrecht, Wilken (2016a): “De Tsjechische Conscience”. In: Humbeeck, Kris e.a. (ed.): De Grote Onleesbare. Hendrik Conscience herdacht. Gent: Academia Press, 238-263.

Engelbrecht, Wilken (2016b): "De Leeuw van Vlaenderen in het Tsjechisch: waarom zo laat en waarom driemaal?" Internationale Neerlandistiek 54, 3: 169-188. 
Engelbrecht, Wilken (2017): "The case of Kaas: The reception of Elsschot's work in the Czech language". In: Kalmthout, Ton van e.a. (ed.): Doing Double Dutch. The International Circulation of Literature from the Low Countries. Leuven: Leuven University Press, 255-268.

Falta, Josef (1937): "V zákopech u Madridu. K vydání reportáže z občanské války ve Španělsku, která vyjde v překladu L. Faltové ve sbírce Obzoru". In: Panorama 15: 107-108.

L.F. (= Lída Faltová) (1934): "Různé zprávy - Johan Fabricius v Praze”. In: Panorama 12: 78-79.

Gera, Judit (2006): "Receptie van de Nederlandstalige cultuur in Hongarije in het laatste decennium (1995-2005)". In: Neerlandica Extra Muros 44, 2: 33-44.

Havlíková, Veronika (2004): "Nederlandstalige literatuur in Tsjechië sinds 1990. Receptie van de Nederlandse en Vlaamse literatuur na de val van de muur". In: Neerlandica extra muros 42 , 3: $26-32$.

Huffel, Antonius J. van $(1939,1946)$ : Nederlandsche schrijvers in vertaling (van Marcellus Emants tot Jan Eekhout). Proeve van eene bibliographie. Leiden: E.J. Brill 1939; Supplement. Leiden: E.J. Brill 1946.

Koch, Jerzy (1993): Ksiązka niderlandzka w przekładzie polskim. Katalog / Het Nederlandse boek in Poolse vertaling. Catalogus. Kłodzko: Witryna Artystów.

Koch, Jerzy \& Morciniec, Norbert (1985): "Bibliografie van Poolse vertalingen uit de Nederlandse literatuur". In: Neerlandica Wratislaviensia 2: 425-480.

Koch, Jerzy \& Morciniec, Norbert (1986): "Bibliografie van Poolse vertalingen uit de Nederlandse literatuur". In: Neerlandica Wratislaviensia 3: 321-364.

Krijtová, Olga, Pellar, Ruben \& Schürová, Petra (1994): Bibliografie překladů z nizozemštiny do češtiny a slovenštiny od roku 1890 do roku 1993. Praha: Jednota tlumočníků a překladatelů.

Krijtová, Olga, Pellar, Ruben \& Schürová, Petra (2003): Doplňky k publikaci Bibliografie překladů z nizozemštiny do češtiny a slovenštiny od roku 1890 do roku 1993. Praha: Jednota tlumočníků a překladateli̊.

Linzbotková, Júlia \& Molnár, Ján (1989): Literatúra Holandska, Portugalska, Belgicka, Írska, Islandu, Grécka a latinská literatúra na Slovensku 1945-1976: bibliográfia prekladov. Bratislava: Alfa.

Maňáková, Marta \& Engelbrecht, Wilken (2006): "Vertalingen van Nederlandstalige literatuur in Slowakije". In: Neerlandica Extra Muros 44, 1: 24-34.

Scheltjens, Werner (2003): Bibliografie van Nederlandse literatuur in Russische vertaling Библиограафия ниделандской литератры на русском язике. Sankt Peterburg: Aleteja.

Szabó, Emese \& Beke, Katalin (2001): "Van Guido tot Het geheim. Nederlandse boeken in Hongaarse vertaling”. In: Acta Neerlandica. Bijdragen tot de Neerlandistiek Debrecen 1: 79-93.

Vaidová, Zuzana (2014): "Het beeld van Frederik van Eeden in Tsjechische vertaling: tijdens zijn leven met een klein uitstapje naar het heden". In: Mededelingen van het Frederik van EedenGenootschap 58: 55-69.

Van Uffelen, Herbert (1993): Bibliographie der modernen niederländischen Literatur in deutscher Übersetzung 1830-1990. Niederlande-Studien 7. Münster: Lit.

Vierhaus, Rudolf (ed.) (2007): Deutsche biographische Enzyklopädie. Bd. 8. Poethen-Schlüter. München: K.G. Saur.

Zach, Alois (2008): "Jos. R. Vilímek”. In: Merhaut, Luboš (ed.): Lexikon české literatury. Osobnosti, díla, instituce. 4. S-Ž. Svazek II U.Ž. Dodátky A-̌̌. Praha: Academia, 1339-1350.

\section{Archiefbronnen}

Památník národního písemnictví fonds 10/97, Melantrich.

Památník národního písemnictví fonds 70/57, Družstevní práce. 
Památník národního písemnictví fonds 169/34, Rudolf Jordan Vonka.

Památník národního písemnictví fonds 345/34-33/69, Jaroslav Kamper.

Wilken Engelbrecht $(* 1962)$ studeerde in Utrecht en Amsterdam Klassieke Talen en Mediëvistiek, in 2003 promoveerde hij te Utrecht op een Middeleeuws-Latijns commentaar op Ovidius. In de jaren 1990-1994 bouwde hij het vak Nederlands in Bratislava en Olomouc opnieuw op. In 2005 habiliteerde hij te Olomouc, waar hij in 2012 tot gewoon hoogleraar letterkunde werd benoemd. Sinds 2011 is hij tevens deeltijdhoogleraar bij de KU Lublin. Zijn interesse gaat uit naar receptie van de Nederlandstalige literatuur in Centraal-Europa, met name in het Tsjechisch.

e-mail: wilken.engelbrecht@upol.cz, wilken.engelbrecht@kul.pl 